https://doi.org/10.35339/msz.2019.83.02.01

УДК 159.91:378.091.212

\author{
M.M. Хаустов
}

Харківський національний медичний університет

\title{
МЕДИКО-ПСИХОЛОГІЧНИЙ ПОГЛЯД НА ПРОБЛЕМУ РОЗЛАДІВ АДАПТАЦІЇ У СТУДЕНТІВ
}

\begin{abstract}
На основі ідентифікації і комплексного оцінювання клініко-психологічних проявів і механізмів формування дезадаптивних станів у студентів-медиків обгрунтовано й розроблено систему заходів їхньої психотерапевтичної корекції. Проведено комплексне обстеження 412 студентів II-V курсів Харківського національного медичного університету обох статей у віці 17-22 років. Усіх обстежених було розподілено на три групи: 1-ша 215 студентів - мешканців східної України; 2-га - 87 студентів - мешканців Луганської та Донецької областей, які поступили до навчання у ХНМУ до початку АТО; 3-тя -110 студентів - переселенців із зони АТО. Показано, що у студентів-переселенців більш високий рівень розладів адаптації, ніж у студентів 1-ї та 2-ї груп. Установлено, що розлади адаптації представлені депресивним, неврастенічним, тривожним та дисоціативним синдромокомплексами. Прогностично значущими в формуванні розладів адаптації $€$ збудливість і неврівноваженість, конфліктність у відносинах, тривожна помисливість, дезорганізація поведінки, неспроможність до саморегуляції, нездатність успішно долати стресові ситуації, діяти за умов невизначеності, ригідність, фіксованість на травматичних і негативних переживаннях. Розроблена система корекції розладів адаптації у студентів-медиків шляхом медико-психологічної підтримки, яка полягала в індивідуалізованому застосуванні психотерапевтичного й психоосвітнього впливів. Відмічено позитивну динаміку психологічного стану: швидку редукцію тривожної та депресивної симптоматики, зниження рівня нервово-психічного напруження, підвищення психофізичної активності студентів та позитивну зміну копінг-стратегії.

Ключові слова: студенти-медики, розлади адаптаиії, тривога, депресія, особливості особистості, психоосвіта, психотерапія.
\end{abstract}

Аналіз даних літератури і постановка проблеми

За сучасних умов гібридної війни, соціальнополітичних та економічних змін відбувається значне підвищення рівня психоемоційного напруження, що призводить до виникнення психологічних проблем у житті кожної людини та, без сумніву, негативно позначається на молоді студентського віку [1].

Серед негативних медико-психологічних наслідків соціального стресу, які спостеріга- ються зараз у населення України, найбільш значущим $\epsilon$ високий ризик поширення й розвитку різноманітних порушень психічної сфери. Серед останніх превалюють як донозологічні (соціально-стресові розлади та окремі ознаки проявів або клінічно сформована психологічна дезадаптація), так і клінічно окреслені психічні розлади невротичного кола $[2,3]$.

Процеси євроінтеграції, що тривають у нашій країні, визначили необхідність глибокого реформування вищої школи в цілому і сис-

$\overline{\text { (C) M.M. Хаустов }}, 2019$ 
теми підготовки медичних кадрів зокрема. Унаслідок цього протягом останніх років істотно змінився режим і підвищилась інтенсивність навчального процесу у студентів-медиків, що призвело до додаткового напруження їхніх адаптаційних можливостей і створило підгрунтя для формування в них дезадаптивних станів $[4,5]$.

Поширеність дезадаптивних розладів у студентській популяції, за даними літератури, коливається від 5,8 до 61,35 \%. Вони зумовлюють зниження працездатності, погіршення навчальної адаптації й академічної успішності, а також якості життя студентів [6, 7].

Сучасний етап розвитку вищої освіти потребує розробки концепції диференційованих психокорекційних і психопрофілактичних заходів, спрямованих на прогнозування, попередження, своєчасну діагностику та лікування розладів адаптації у студентів [8].

Пріоритетним завданням сучасної медичної психології $є$ ефективне вирішення питання особливостей проявів і механізмів розвитку дезадаптивних станів за умов соціального стресу, оптимізація надання кваліфікованої медико-психологічної допомоги та психопрофілактики подібних хворобливих станів $[9,10]$.

Викладене зумовило актуальність і необхідність проведення даного дослідження.

Мета дослідження на основі ідентифікації та комплексного оцінювання клініко-психологічних проявів та механізмів формування дезадаптивних станів у студентів-медиків обгрунтувати та розробити систему заходів їхньої психотерапевтичної корекції.

\section{Контингент, матеріали і методи}

Для досягнення поставленої мети відповідно до вимог статей 1,11 та 12 Закону України «Про психіатричну допомогу» та Кодексу етики Всесвітньої медичної асоціації (Декларація Гельсінкі) нами було проведено комплексне клініко-анамнестичне, клініко-психопатологічне та психодіагностичне обстеження 412 студентів Харківського національного медичного університету обох статей (147 чоловіків та 265 жінок) у середньому віці $(19,5 \pm$ $2,5)$ року.

На момент дослідження 35,1 \% студентів визнали свої матеріальні умови для життя як хороші, 40,8 \% - як середні, 20,4 \% - як задовільні, 3,7 \% - як незадовільні. Серед обстежених студентів 59,9\% проживали з батьками, 40,1 \% - окремо від них.
У ході роботи нами виділено три групи досліджуваних: 1-ша - 215 студентів - мешканців Харківської області; 2-га - 87 студентів, мешканців Луганської та Донецької областей, які вступили на навчання у ХНМУ до початку АТО; 3-тя - 110 студентів - вимушених переселенців із зони АТО.

\section{Результати та їх обговорення}

Як показали результати дослідження, студенти-переселенці виявляють більш високий рівень розладів адаптації, ніж студенти 1-ї та 2-ї груп, дезадаптивні стани різного ступеня вираженості виявлено у $27,07 \%$ обстежених 1-ї групи, 36,4 \% 2-ї групи та 92,21 \% 3-ї групи. При цьому 0,5 \% студентів 1-ї групи, 2,2 \% студентів 2-ї групи та 25,4 \% студентів 3-ї групи притаманний високий рівень дезадаптації; 2,4 \% студентів 1-ї групи, 9,2 \% - 2-ї та 36,4 \% 3-ї групи - виражений рівень дезадаптації; 24,1 \% студентів 1-ї групи, 25,0 \% - 2-ї групи та $30,4 \%$ студентів 3-ї групи - помірний рівень дезадаптації.

Як показав аналіз рівнів тривоги та депресії, за клінічною шкалою тривоги і депресії у 46,1 \% студентів 3-ї групи виявлені клінічні прояви тривоги у порівнянні з 4,2\% студентів 1-ї та 6,6 \% 2-ї груп. Субклінічні прояви тривоги виявлені у 40,2 \% студентів 1-ї, 12,5\% 2-ї та 8,4 \% - 3-ї групи. Клінічні прояви депресії характерні для 32,4 \% студентів 3-ї групи, $18,2 \%$ студентів 2-ї групи та 2, $4 \%$ - 1-ї групи, а субклінічні прояви депресії для 33,$1 ; 15,6$ та 4,9\% відповідно.

Аналіз рівня нервово-психічної напруги у структурі дезадаптивних станів показав переважання інтенсивної (помірної) у студентів 1-ї та 2-ї груп та екстенсивної (надмірної) напруги в обстежених 3-ї групи.

Отримані в ході роботи дані дозволили систематизувати розлади адаптації в обстежених студентів та виділити депресивний $(22,1 \%$ обстежених 1-ї групи, 23, 1 \% 2-ї групи та 25,2 \% обстежених 3-ї групи), неврастеничний (27,8; 25,4 та 22,2 \% обстежених відповідно), тривожний (24,5 \% обстежених 1-ї групи, 26,6 \% 2-ї групи та 25,3 \% 3-ї групи) та дисоціативний $(25,6 ; 24,9$ та 26,8 \% відповідно) синдромокомплекси.

Як показав аналіз особливостей особистості обстежених студентів, за шкалами СБОО 3 розладами адаптації у $32,1 \%$ студентів 1-ї групи, 34,1 \% - 2-ї групи та 38,9 \% обсте- 
жених 3-ї групи характерні піки за шкалою депресії; у 19,8; 22,1 та 28,8 \% обстежених відповідно - піки за шкалою психастенії; у 21,1 \% студентів 1-ї групи, 19,5 \% 2-ї групи та 20,2 \% обстежених 3-ї групи - за шкалою іпохондрії.

Для обстежених студентів 3 розладами адаптації притаманні збудливість і неврівноваженість, конфліктність у відносинах, тривожна помисливість, дезорганізація поведінки, неспроможність до саморегуляції, нездатність успішно долати стресові ситуації, діяти в умовах невизначеності, ригідність, фіксованість на травматичних і негативних переживаннях.

3 метою корекції розладів адаптації у студентів-медиків нами було розроблено систему їх медико-психологічної підтримки, яка включала індивідуалізоване застосування психотерапевтичного та психоосвітнього впливів.

Психотерапевтична програма включала чотири послідовних етапи: I - первинної адаптації до психотерапевтичного процесу; II психоосвітніх впливів; III - стабілізації емоційного стану; IV - профілактика рецидиву дезадаптивних станів.

Психотерапевтична корекція при депресивному варіанті розладів адаптації включала використання раціональної психотерапії (класичний варіант П. Дюбуа, 1912), когнітивно-поведінкову терапію Бека (А.T. Beck, 2006) та арт-терапію у техніці «Малюнок себе». При неврастеничному варіанті ми використовували когнітивно-поведінкову терапію Бека (А.T. Beck, 2006), особистісно-орієнтовану психотерапію (Б.Д. Карвасарський, Г.Л. Інсуріна, В.А. Ташликов, 1994), психотонічний варіант аутогенного тренування (А.М. Шогама, К.І. Мировського, 1963); при тривожному варіанті - когнітивно-поведінкову терапію Бека (А.T. Beck, 2006), особистісно-орієнтовану психотерапію (Б.Д. Карвасарський, Г.Л. Інсуріна, В.А. Ташликов, 1994) та арт-терапію у техніці «Зірка почуттів». При дисоціативному варіанті використовувались короткотермінова психодинамічна психотерапія (Б.Д. Карвасарський, 1999), когнітивно-поведінкова терапія Бека (А.T. Beck, 2006), аутогенне тренування в модифікації М.С. Лебединського, Т.Л. Бортнік (1969).

Смислотворчим елементом розробленої моделі психотерапевтичного включення була психоосвіта $з$ використанням інформаційних модулів та комунікативної терапії та проблемно-орієнтованих дискусій.
Необхідно підкреслити, що, враховуючи специфіку психотравмуючих обставин студентів-переселенців та їх необхідність адаптуватися не лише до вимог навчання, але і до нового соціального статусу - вимушено переселеної особи, а також більшу вираженість тривожно-депресивних проявів, психотерапевтична програма для цієї групи була змінена в бік збільшення об'єму та тривалості психотерапевтичних інтервенцій.

На тлі проведеної психотерапевтичної корекції відмічена позитивна динаміка психологічного стану: швидка редукція тривожної та депресивної симптоматики, зниження рівня нервово-психічної напруги, підвищення психофізичної активності студентів.

Психотерапевтичне втручання сприяло позитивним змінам копінг-стратегій. До психотерапевтичного втручання у $36,2 \%$ студентів 3 розладами адаптації спостерігався копінг, орієнтований на уникнення, у 19,7 \% - на вирішення проблем, у 44,1 \% - на емоції. Після завершення психотерапії у 2,9 \% студентів реєстрували копінг, орієнтований на уникнення; у 92,3 \% - копінг, орієнтований на вирішення проблеми; у 4,8 \% студентів - копінг, орієнтований на емоції.

\section{Висновки}

1. Стани дезадаптації у студентів-медиків представлені депресивним (у 22,1 \% обстежених 1-ї групи, у 23,1 \% - 2-ї та у 25,2 \% -3-ï), неврастеничним (у 27,8; 25,4 та 22,7 \% відповідно), тривожним (у 24,5 \% обстежених 1-ї групи, у $26,6 \%$ - 2-і та у $25,3 \%$ - 3-ï) та дисоціативним (у 25,6; 24,9 та 26,8 \% відповідно) синдромокомплексами.

2. Доведено ефективність системи психотерапевтичної корекції станів дезадаптації у студентів медичного університету, яка складається $з$ чотирьох послідовних етапів: I формування комплаєнса, первинної адаптації до психотерапевтичного процесу; II - психоосвітній, спрямований на нівелювання наявного у студентів дефіциту знань щодо механізмів формування та особливостей перебігу розладів адаптації; III - корекційний, спрямований на стабілізацію емоційного стану, формування адаптивних форм поведінки; IV - закріплення й підтримки результатів шляхом потенціювання позитивних емоцій, профілактика рецидиву дезадаптивних станів. 


\section{Список літератури}

1. Kozhyna $H$. The phenomenon of psychological adaptation to the professional activities of doctors / H. Kozhyna, V. Mykhaylov, V. Vyun // European psychiatry. The Journal of the European psychiatric association. - 2017. - Vol. 41. - P. 690-691.

2. Марков А. Р. Клінічна варіативність дезадаптивних станів у цивільного населення в умовах інформаційно-психологічної війни / А. Р. Марков // Психіатрія, неврологія та медична психологія. 2016. - T. 3, № 2 (6). - С. 98-105.

3. Лещина I. В. Скринінгова діагностика непсихотичних психічних розладів у студентів-медиків / І. В. Лещина // Вісник проблем біології і медицини. - 2011. - Т. 1, № 2. - С. 131-135.

4. Vyun $V$. Modern system of medical-psychological support of the internship doctors at the stage of postgraduate education / V. Vyun // Inter Collegas. - 2017. - № 3 (4). - P. 139-141.

5. Аймедов К. В. Професійна мобільність майбутніх фахівців у процесі навчання у ВНЗ: компетентнісний підхід / К. В. Аймедов, С. М. Стрельбицька // Наукові праці : науково-методичний журнал. Серія «Педагогіка». - 2014. - Т. 251, № 239. - С. 49-52.

6. Пшук Н. Г. Роль психосоціальних чинників в генезі соціальної дезадаптації у студентської молоді / Н. Г. Пшук, Д. П. Слободянюк // Український вісник психоневрології. - 2015. - Т. 23, № 2 (83). - C. 86-91.

7. Киосева У. В. Психопатологическая характеристика эмоциональной сферы у студентов младших курсов / Е. В. Киосева // Український вісник психоневрології. - 2016. - Т. 24, № 1 (86). - С. 60-63.

8. Чабан О. С. Шляхи підвищення ефективності навчання студентів за спеціальністю «Медична психологія» / О. С. Чабан, О. О. Хаустова, Л. Є. Трачук // Медична психологія. - 2016. - № 1. - С. 3-8.

9. К проблеме адаптационного синдрома студентов младших курсов вузов III-IV уровней аккредитации / А. М. Кожина, М. В. Маркова, Е. Г. Гриневич, Е.А. Зеленская // Архів психітрії. - 2011. T. 17, № 4 (67). - C. 32-35.

10. Коваленко М. В. Структурний аналіз перфекціонізму у студентів вищих навчальних медичних закладів / М. В. Коваленко // Український вісник психоневрології. - 2014. - Т. 22, № 3 (80). - С. 65-68.

11. Інформаційний лист про нововведення в системі охорони здоров'я № 200-2017. Метод лікування розладів адаптації / Кожина Г. М., В’юн В. В., Зеленська К. О. - К., 2017. - 4 с.

\section{References}

1. Kozhyna H., Mykhaylov V., Vyun V. (2017). The phenomenon of psychological adaptation to the professional activities of doctors. European psychiatry. The Journal of the European psychiatric association, vol. 41, pp. 690-691.

2. Markov A.R. (2016). Klinichna variatyvnist dezadaptyvnykh staniv u tsyvilnoho naselennia $v$ umovakh informatsiino-psykholohichnoi viiny [Clinical variability of maladaptive conditions in civilians in conditions of information and psychological warfare]. Psykhiatriia, nevrolohiia ta medychna psykholohiia Psykhiatriia, Nevrolohiia ta Medychna Psykholohiia, vol. 3, № 2 (6), pp. 98-105 [in Ukrainian].

3. Leshchyna I.V. (2011). Skryninhova diahnostyka nepsykhotychnykh psykhichnykh rozladiv u studentiv-medykiv [Screening diagnostics of non-psychotic psychiatric disorders in medical students]. Visnyk problem biolohii i medytsyny - Bulletin of Problems of Biology and Medicine, vol. 1, № 2, pp. 131-135 [in Ukrainian].

4. Vyun V. (2017). Modern system of medical-psychological support of the internship doctors at the stage of postgraduate education. Inter Collegas, № 3 (4), pp. 139-141.

5. Aimedov K.V., Strelbytska S.M. (2014). Profesiina mobilnist maibutnikh fakhivtsiv u protsesi navchannia u VNZ: kompetentnisnyi pidkhid [Professional Mobility of Future Professionals in Higher Education: A Competent Approach]. Naukovi pratsi: Naukovo-metodychnyi zhurnal. Ceriia «Pedahohika»Scientific works: Scientific and Methodological Journal. Pedagogy Series, vol. 251, № 239, pp. 49-52 [in Ukrainian].

6. Pshuk N.H., Slobodianiuk D.P. (2015). Rol psykhosotsialnykh chynnykiv v henezi sotsialnoi dezadaptatsii u studentskoi molodi [The role of psychosocial factors in the genesis of social maladaptation in student youth]. Ukrainskyi visnyk psykhonevrolohii - Ukrainian Journal of Psychoneurology, vol. 23, № 2 (83), pp. 86-91 [in Ukrainian]. 
7. Kioseva E.V. (2016). Psikhopatolohicheskaia kharakteristika emotsionalnoi sfery u studentov mladshikh kursov [Psychopathological characteristics of the emotional sphere in junior students]. Ukrainskyi visnyk psykhonevrolohii - Ukrainian Journal of Psychoneurology, vol. 24, № 1 (86), pp. 60-63 [in Russian].

8. Chaban O.S., Khaustova O.O., Trachuk L.Ie. (2016). Shliakhy pidvyshchennia efektyvnosti navchannia studentiv za spetsialnistiu «Medychna psykholohiia» [Ways to improve the effectiveness of students' training in the specialty «Medical Psychology»]. Medychna psykholohiia-Medical Psychology, № 1, pp. 3-8 [in Ukrainian].

9. Kozhyna A.M., Markova M.V., Hrinevich Ye.H., Zelenskaia Ye.A. (2011). K probleme adaptatsionnoho sindroma studentov mladshikh kursov vuzov III-IV urovnei akkreditatsii [To the problem of adaptation syndrome of junior students of universities of III-IV levels of accreditation]. Arkhiv psykhiatrii-Psychiatry Archive, vol. 17, № 4 (67), pp. 32-35 [in Russian].

10. Kovalenko M.V. (2014). Strukturnyi analiz perfektsionizmu u studentiv vyshchykh navchalnykh medychnykh zakladiv [Structural analysis of perfectionism in students of higher educational establishments]. Ukrainskyi visnyk psykhonevrolohii - Ukrainian Journal of Psychoneurology, vol. 22, № 3 (80), pp. 65-68 [in Ukrainian].

11. Kozhyna H.M., Viun V.V., Zelenska K.O. (2017). Informatsiinyi lyst pro novovvedennia v systemi okhorony zdorovia № 200-2017. Metod likuvannia rozladiv adaptatsii [Health Newsletter № 200-2017. A method of treating adaptation disorders]. Kyiv, 4 p. [in Ukrainian].

\section{М.Н. Хаустов}

МЕДИКО-ПСИХОЛОГИЧЕСКИЙ ВЗГЛЯД НА ПРОБЛЕМУ РАССТРОЙСТВ АДАПТАЦИИ СТУДЕНТОВ

На основе идентификации и комплексной оценки клинико-психологических проявлений и механизмов формирования дезадаптивных состояний у студентов-медиков обоснована и разработана система мер их психотерапевтической коррекции. Проведено комплексное обследование 412 студентов II-V курсов Харьковского национального медицинского университета обоих полов в возрасте 17-22 лет. Все обследованные были разделены на три группы: 1-я - 215 студентов - жителей восточной Украины; 2-я - 87 студентов - жителей Луганской и Донецкой областей, поступивших на учебу в ХНМУ до начала АТО; 3-я - 110 студентов - переселенцев из зоны АТО. Показано, что у студентов-переселенцев более высокий уровень расстройств адаптации, чем у студентов 1-й и 2-й групп. Установлено, что расстройства адаптации представлены депрессивным, неврастеничним, тревожным и диссоциативным синдромокомплексами. Прогностически значимыми в формировании расстройств адаптации являются возбудимость и неуравновешенность, конфликтность в отношениях, тревожная мнительность, дезорганизация поведения, неспособность к саморегуляции, неспособность успешно преодолевать стрессовые ситуации, действовать в условиях неопределенности, ригидность, фиксированность на травматических и отрицательных переживаниях. Разработана система коррекции расстройств адаптации у студентов-медиков путем медико-психологической поддержки, которая заключалась в индивидуализированном применении психотерапевтического и психообразовательного воздействий. Отмечена положительная динамика психологического состояния: быстрая редукция тревожной и депрессивной симптоматики, снижение уровня нервно-психического напряжения, повышение психофизической активности студентов, положительное изменение копингстратегии.

Ключевые слова: студенты-медики, расстройства адаптации, тревога, депрессия, особенности личности, психообразование, психотерапия.

\section{M.M. Khaustov}

MEDICAL-PSYCHOLOGICAL VIEW ON THE PROBLEM OF ADAPTATION DISORDERS IN STUDENTS

Based on the identification and comprehensive assessment of clinical and psychological manifestations and mechanisms of the formation of maladaptive conditions in medical students, a system of measures for their psychotherapeutic correction has been substantiated and developed. A comprehensive survey of 412 students of II-V academic years of the Kharkov National Medical University of both sexes aged 1722 was conducted. All examined were divided into three groups: $1^{\text {st }}$ group are 215 students, residents of eastern Ukraine; $2^{\text {nd }}$ group are 87 students, residents of the Lugansk and Donetsk regions, who entered study at KNMU before the start of the ATO; $3^{\text {rd }}$ group are 110 students, immigrants from the anti-terrorist operation zone. It is shown, that students-migrants have a higher level of adaptation disorders than students 
of the $1^{\text {st }}$ and $2^{\text {nd }}$ groups. It has been established that adaptation disorders were represented by depressive, neurasthenic, anxious and dissociative syndrome complexes. Excitability and imbalance, conflict in relationships, anxious suspiciousness, disorganization of behavior, inability to self-regulation, inability to successfully overcome stressful situations, act in conditions of uncertainty, rigidity, fixation on traumatic and negative experiences are predictively significant in the formation of adaptation disorders. A system for the correction of adaptation disorders in medical students through medical and psychological support was developed, which consisted in the individualized use of psychotherapeutic and psycho-educational influences. Positive dynamics of the psychological state was noted: a rapid reduction in anxiety and depressive symptoms, a decrease in the level of psychological stress, an increase in the psychophysical activity of students, a positive change in coping strategy.

Keywords: medical students, adaptation disorders, anxiety, depression, personality traits, psychoeducation, psychotherapy.

Надійшла 10.04.19

\section{Відомості про автора}

Хаустов Максим Миколайович - кандидат медичних наук, доцент, доцент кафедри психіатрії, наркології та медичної психології Харківського національного медичного університету.

Адреса: 61022, м. Харків, пр. Науки, 4, Харківський національний медичний університет.

Тел.: +38(066)009-98-08.

E-mail: haustov217@gmail.com.

ORCID: https://orcid.org/0000-0002-8613-2172. 